\title{
Localized corrosion effects and modifications of acidic and alkaline slurries on copper chemical mechanical polishing
}

\author{
Tzu-Hsuan Tsai, Shi-Chern Yen* \\ Department of Chemical Engineering, National Taiwan University, Taipei 106-17, Taiwan
}

Received 14 May 2002; received in revised form 14 May 2002; accepted 1 November 2002

\begin{abstract}
This study demonstrates the CMP performance can be enhanced by modifying the corrosion effects of acidic and alkaline slurries on copper. A corrosion test-cell with a polishing platform is connected with the potentiostat to investigate the corrosion behaviors of copper CMP in various alumina slurries. Experiments show that the slurry needs to be maintained in acidic $\mathrm{pH}<4.56$ or alkaline $\mathrm{pH}>9.05$ surroundings and thus better dispersion of alumina particles and less residual contaminant on copper surface can be obtained. The surface defects after copper CMP using acidic and alkaline slurries are described by pitting corrosion mechanisms, and these mechanisms can be regarded as a basis to modify their corrosion effects. Experimental results indicate that it is necessary to modify the dissolution of $\mathrm{HNO}_{3}$ and oxidization of $\mathrm{NH}_{4} \mathrm{OH}$ for copper CMP slurries. Consequently, the slurries of 5 wt. $\% \mathrm{HNO}_{3}$ by adding 0.1 wt. $\%$ BTA or 5 wt. $\% \mathrm{KNO}_{3}$ by adding 1 wt. $\% \mathrm{NH}_{4} \mathrm{OH}$ achieve good CMP performance for copper with higher CMP efficiency factor (CMPEF), 1460 and 486, and lower surface roughness $\left(R_{\mathrm{q}}\right), 4.019$ and $3.971 \mathrm{~nm}$, respectively. It is found that AFM micrographs can support the effectiveness of corrosion modifications for copper CMP in various slurry chemistries.
\end{abstract}

(C) 2003 Elsevier Science B.V. All rights reserved.

Keywords: Chemical mechanical polishing; Copper; Pitting corrosion; Alumina slurry; Potentiodynamic curve; Surface roughness

\section{Introduction}

Copper has been the material favored for integrated circuit manufacturers, owing to its excellent electromigration resistance and low electrical resistance. One feasible means of integrating copper technology is by using dual damascene procedure in which chemical mechanical polishing (CMP) is employed as a viable method for planarizing the surface globally [1]. The CMP has been successfully applied in semiconductor production to create tungsten interconnects [2], and

\footnotetext{
* Corresponding author. Tel.: +886-2-23630397; fax: + 886-2-23630397.

E-mail address: scyen@ccms.ntu.edu.tw (S.-C. Yen).
}

previous literature has confirmed that the CMP mechanism of tungsten metal comprises the cyclic chemical formation of a metal passive film and its subsequent mechanical removal [3]. However, copper is softer and more sensitive to corrosion than tungsten, and the slurry composition and corrosion mechanisms of copper during CMP may be more complicated. Therefore, more thoroughly understanding the corrosion effects on removal rates and surface finishing is critical to achieving copper metallization.

A commonly used CMP utilizes abrasive particles that are suspended in colloidal slurry. Different additives or reagents can be combined with the slurry to provide high removal rates, good planarity and high selectivity [4-6], and to improve the dispersion of 
abrasive particles and rheological properties of the slurry $[7,8]$. As reported, copper CMP can be performed in either acidic or neutral or alkaline media with different function additives. For examples, an oxidizer is generally added to accelerate oxidization actions during copper CMP, while a film-forming agent inhibits the dissolution of surface being polishing [9]. Still dispersing agents or surfactants can be used to improve the uniformity and reduce the wafer defects and residual particles [10]. However, the variety of polymer surfactants added into slurries results in more complicated problems of post-cleaning of CMP. In order to avoid coagulating of particles, choosing the slurry where the materials carry the same charge to repel each other is thinkable [11]. On the other hand, having corrosion behaviors between the copper surface and the slurry in hand is thus important, and modifying corrosion attack in various slurries must be studied by use of in situ electrochemical measurements [12]. Herein we try to illustrate the localized attack on copper surface by using the pitting mechanisms. As mentioned above, the planarization of metal CMP is achieved by the cyclic chemical formation of a metal passive film and its subsequent mechanical removal. During this removal process, it can be regarded as a forced non-uniform breakdown of the surface layer or passive film. The breakdown phenomenon results in the localized corrosion and initiates the pitting behaviors [13]. Thus, it is important to control the pitting actions of copper CMP by modifying the corrosion environment. If the pitting propagation does not be inhibited, then the pit is formed seriously. Hence the global planarization of CMP cannot be achieved. However, few studies have examined the corrosion mechanisms of copper CMP by pitting. Still little attention has been given to the corrosion modification of the relation between mechanical and chemical actions.

This work investigated the localized corrosion characteristics of copper CMP in acidic and alkaline slurries. The defined indication of modifications has been proven to consist with the average roughness of copper surface and reasonably to explain the repassivation ability. One is CMP efficiency factor (CMPEF), the ratio of removal rates (RR) to corrosion rates (CR); the other is the differentiation of $R R$ with respect to the pressure. It is found the AFM micrographs agree well with the localized corrosion mechanisms constructed by using the electrochemical results and the defined indications.

\section{Experimental}

To investigate the corrosion effects of various chemical compositions on copper CMP, the slurries were prepared by use of analytical grade reagents. The polishing slurry was prepared comprising only one abrasive, one corrosion enhancer or one film-forming agent, as listed in Table 1, where the abrasive was $50 \mathrm{~nm} \alpha$-alumina particle, and $5 \mathrm{wt} . \%$ for all measurements. The colloid slurry was prepared from a high sear stress condition in a mixer with high rotation speed to maintain a good dispersion of abrasive particles and their pHs were adjusted by the addition of $\mathrm{HNO}_{3}$ or $\mathrm{NH}_{4} \mathrm{OH}$. An acoustic spectrometer model DT-1200 was used to determine the zeta potentials of materials.

The copper CMP was simulated in a corrosion testcell with the specially designed base as the polishing platform. Fig. 1 schematically displays this polishing setup. Electroplated copper films with a thickness of

Table 1

Specifications of slurry design for copper CMP

\begin{tabular}{llllll}
\hline Specification & \multicolumn{2}{l}{ Slurry type } & & & \\
\cline { 2 - 6 } & DI water & $1-10 \mathrm{wt} \%$ & $1-10 \mathrm{wt} . \% \mathrm{HNO}_{3}+$ & $1-5$ wt. $\%$ & $1-5$ wt. $\% \mathrm{NH}_{4} \mathrm{OH}+$ \\
& & $\mathrm{HNO}_{3}$ & 0.1 wt. $\%$ BTA & $\mathrm{NH}_{4} \mathrm{OH}$ & $\sim$ wt. $\% \mathrm{KNO}_{3}$ \\
\hline pH range & 6.98 & $\sim 1.0$ & $\sim 1.0$ & $\sim 12.0$ & $\sim 11.5$ \\
Abrasive 5 wt.\% & $\alpha-\mathrm{Al}_{2} \mathrm{O}_{3}$ & $\alpha-\mathrm{Al}_{2} \mathrm{O}_{3}$ & $\alpha-\mathrm{Al}_{2} \mathrm{O}_{3}$ & $\alpha-\mathrm{Al}_{2} \mathrm{O}_{3}$ & $\alpha-\mathrm{Al}_{2} \mathrm{O}_{3}$ \\
Corrosion enhancer & - & $\mathrm{HNO}_{3}$ & $\mathrm{HNO}$ & $\mathrm{NH}_{4} \mathrm{OH}$ & $\mathrm{KNO}_{3}, \mathrm{NH}_{4} \mathrm{OH}$ \\
Film-forming condition & - & - & BTA & Alkaline solution & Alkaline solution \\
\hline
\end{tabular}




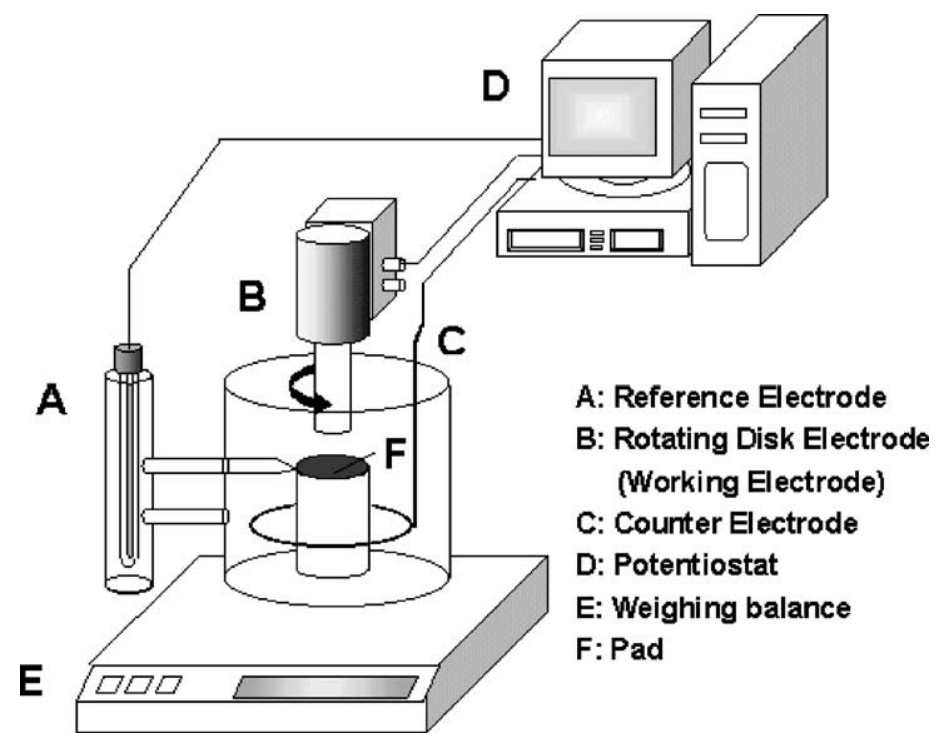

Fig. 1. The schematic representation of a corrosion test-cell used to measure the corrosion behaviors of copper films during CMP.

around $4 \mu \mathrm{m}$ as the working electrode were prepared by use of a $\mathrm{CuSO}_{4} / \mathrm{H}_{2} \mathrm{SO}_{4}$-based system. Meanwhile, a platinum counter electrode and $\mathrm{Ag} / \mathrm{AgCl}$ reference electrode were used for the potentiodynamic measurements. The reference electrode was inserted into the corrosion cell through a Luggin tube, the tip of which was around $2 \mathrm{~mm}$ from the working electrode. The area abraded by the polishing cloth was $0.197 \mathrm{~cm}^{2}$. The downward force during polishing was varied from 0 to $68947.6 \mathrm{~N} / \mathrm{m}^{2}$, and was measured using a weighing balance supporting the entire electrochemical cell. In this configuration, the copper-plated film rotated on the pad under pressure. A long napped synthetic rayon cloth (Buehler Microcloth) was used as the polishing pad for the corrosion experiments herein.

The electrochemical experiments were conducted by use of a potentiostat/galvanostat (EG\&G model 273), while the corrosion software EG\&G model 352 was adopted for potentiodynamic measurements. The electrochemical method of chronopotentiometry was employed before and after CMP to measure the thickness of the copper deposited film, allowing the copper removal rate to be calculated. The potentiodynamic data obtained with a voltage scan rate of $5 \mathrm{mV} / \mathrm{s}$ were used to measure the corrosion current densities and potential. Meanwhile, the corrosion current density was converted to the corresponding electrochemical corrosion rate in namometer per minute by use of Faraday's law. Moreover, according to corrosion theory [13], the shift trend of potentiodynamic curves with various slurry concentrations should provide information regarding the corrosion mechanisms of copper CMP.

In order to measure the surface profile, copper was punched to disk of $3 \mathrm{in}$. in diameter for polisher operating at $34473.80 \mathrm{~N} / \mathrm{m}^{2}$ and $8.376 \mathrm{rad} / \mathrm{s}$ with IC1000/SUBA IV pad. An atomic force microscopy (AFM) model Nanoscope IIIa with tapping mode was used to characterize the surface morphology and average roughness of samples before and after CMP using various slurries.

\section{Results and discussion}

\subsection{Particulate contamination}

The zeta potentials of materials of interest to copper CMP are shown in Fig. 2. The corresponding isoelectric points (IEP), i.e. the $\mathrm{pH}$ with zero charge on the surface, were measured to be $9.05,4.56$ and 7.64 for $\alpha-\mathrm{Al}_{2} \mathrm{O}_{3}$, copper and cuprous oxide, respectively. In order to minimize the particulate contamination on the copper surface, the same sign of surface charges between materials and copper to repel each other is necessary. As shown in Fig. 2, at acidic $\mathrm{pH}<4.56$ and alkaline $\mathrm{pH}>9.05$, the copper always 


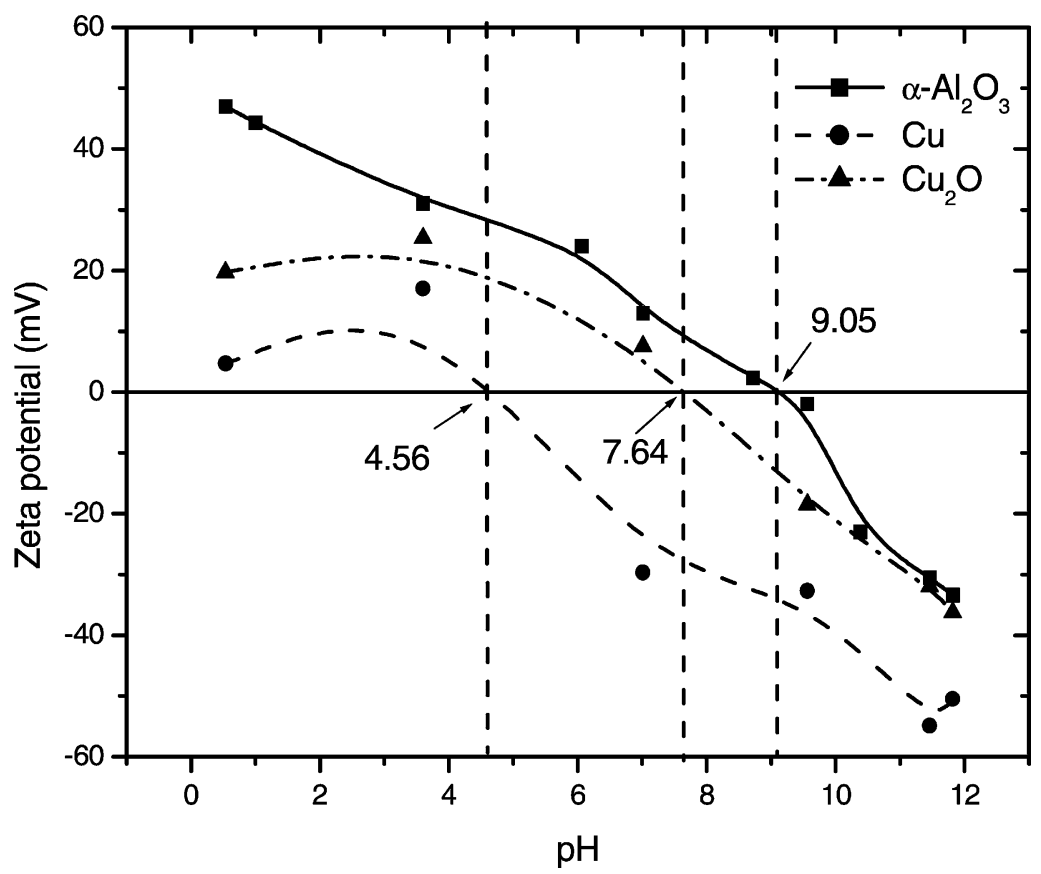

Fig. 2. Zeta potentials of $\alpha$-alumina, copper and cuprous oxide as a function of $\mathrm{pH}$. The vertical lines represent the isoelectric points of $\alpha$ alumna (9.05), copper (4.56) and cuprous oxide (7.64).

had the repulsive electrostatic force with $\alpha-\mathrm{Al}_{2} \mathrm{O}_{3}$ and cuprous oxide. However, $\alpha-\mathrm{Al}_{2} \mathrm{O}_{3}$ and copper with opposite charges at $\mathrm{pH} 4.56-7.64$ would result in alumina contamination. Then at $\mathrm{pH} 7.64-9.05$, i.e. near a neutral solution, both $\mathrm{Al}_{2} \mathrm{O}_{3}$ and cuprous oxide would be remained on copper surface. In acidic and alkaline slurries, therefore, the dispersion of $\alpha-\mathrm{Al}_{2} \mathrm{O}_{3}$ particles in slurries is more stable, and the adhesion of residual materials on copper surface is avoidable. Next, the corrosion effects of acidic and alkaline slurries are investigated, respectively.

\subsection{Corrosion effects of acidic and alkaline solutions}

\subsection{1. $\mathrm{HNO}_{3}$ slurry}

Fig. 3 shows the effects of $\mathrm{HNO}_{3}$ concentrations on the polarization curves of copper and the corrosion parameters are listed in Table 2. It displays that the cathode polarization curve moves right with increasing $\mathrm{HNO}_{3}$ concentration and the anodic region does not almost shift. In addition, the corrosion potential and corrosion current density are determined by the intersections of cathodic and anodic curves.
Therefore, both of these parameters would increase with increasing $\mathrm{HNO}_{3}$ concentration. According to corrosion theory [13], the rightward shift of the cathode polarization curves reveal that corrosion is mainly accelerated by cathode reactions. Hence, $\mathrm{HNO}_{3}$ is a strong copper oxidizer capable of rapidly attacking copper. Additionally, the potentiodynamic curves in Fig. 3 exhibit no steep slope in the anodic range, meaning that no passive films are formed on the copper surface. Consequently, copper may directly dissolve in $\mathrm{HNO}_{3}$ solutions.

The corrosion potentials and $\mathrm{pH}$ in $\mathrm{HNO}_{3}$ solutions are listed in Table 2. The corresponding range and the equilibrium components of Pourbaix diagram are drawn on Fig. 4 [14]. It indicates that copper is corroded to $\mathrm{Cu}^{2+}$ in $\mathrm{HNO}_{3}$ solutions, and no oxide film is formed to protect the surface from corrosion. Copper dissolution is thus expected to be the dominant reaction in $\mathrm{HNO}_{3}$ slurries. As mentioned above, copper $\mathrm{CMP}$ in $\mathrm{HNO}_{3}$-based slurries contains the following electrochemical reactions:

Anode:

$$
\mathrm{Cu} \rightarrow \mathrm{Cu}^{2+}+2 \mathrm{e}^{-}, \quad E^{0}=0.337 \mathrm{~V}
$$




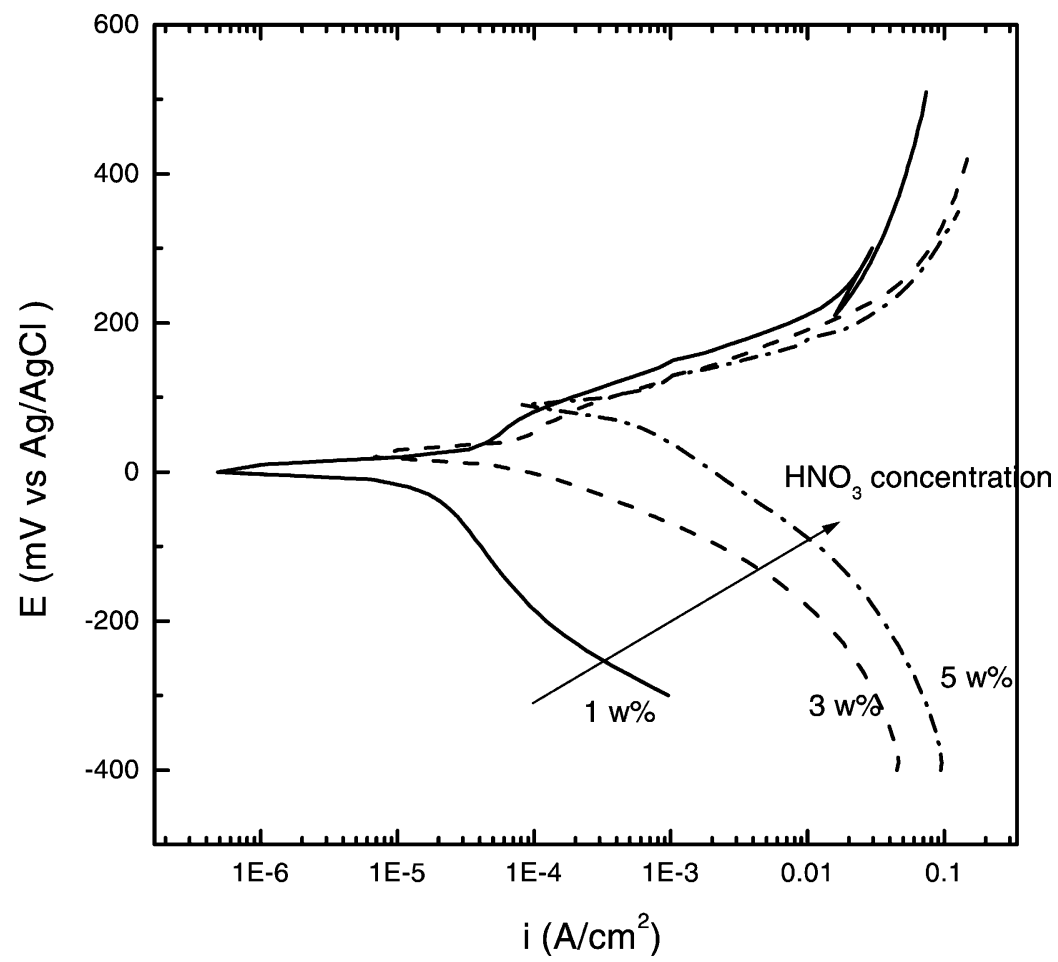

Fig. 3. Potentiodynamic curves of copper in the slurries of various $\mathrm{HNO}_{3}$ concentrations without abrasion.

Cathode:

$$
\begin{aligned}
& \mathrm{NO}_{3}{ }^{-}+3 \mathrm{H}^{+}+2 \mathrm{e}^{-} \rightarrow \mathrm{HNO}_{2}+\mathrm{H}_{2} \mathrm{O}, \\
& E^{0}=0.934 \mathrm{~V} \\
& \mathrm{NO}_{3}{ }^{-}+4 \mathrm{H}^{+}+3 \mathrm{e}^{-} \rightarrow \mathrm{NO}+2 \mathrm{H}_{2} \mathrm{O}, \\
& E^{0}=0.957 \mathrm{~V} \\
& \mathrm{O}_{2}+4 \mathrm{H}^{+}+4 \mathrm{e}^{-} \rightarrow 2 \mathrm{H}_{2} \mathrm{O}, \\
& E^{0}=1.229 \mathrm{~V}
\end{aligned}
$$

Even though the high removal rate for copper CMP in the slurry of $5 \mathrm{wt} . \% \mathrm{HNO}_{3}$ can be attained from the experiment, as listed in Table 2, the over high corrosion rate which is calculated from the measured corrosion current density with abrasion, is contained in this slurry. Consequently, the corrosion condition can be described by the phenomenon of copper

\begin{tabular}{|c|c|c|c|c|c|}
\hline Solution & $\mathrm{pH}$ & $E_{\text {corr }}(\mathrm{mV})$ vs. $\mathrm{Ag} / \mathrm{AgCl}$ & $i_{\text {corr }}\left(\mathrm{A} / \mathrm{cm}^{2}\right)$ & $\mathrm{RR}^{\mathrm{a}}(\mathrm{nm} / \mathrm{min})$ & $\mathrm{CR}^{\mathrm{a}}(\mathrm{nm} / \mathrm{min})$ \\
\hline \multicolumn{6}{|l|}{$\mathrm{HNO}_{3}$} \\
\hline $1 \mathrm{wt} . \%$ & 1.27 & 81.2 & $8.2 \times 10^{-4}$ & 467 & 26.46 \\
\hline 3 wt. $\%$ & 1.15 & 107.1 & $2.6 \times 10^{-3}$ & 525 & 46.30 \\
\hline 5 wt. $\%$ & 0.86 & 119.3 & $5.8 \times 10^{-3}$ & 589 & 37.48 \\
\hline \multicolumn{6}{|l|}{$\mathrm{NH}_{4} \mathrm{OH}$} \\
\hline 1 wt. $\%$ & 11.2 & -451.11 & $5.6 \times 10^{-5}$ & 275 & 0.140 \\
\hline 3 wt. $\%$ & 11.7 & -488.6 & $7.0 \times 10^{-5}$ & 336 & 0.036 \\
\hline 5 wt. $\%$ & 12.3 & -534.4 & $9.1 \times 10^{-5}$ & 270 & 0.080 \\
\hline
\end{tabular}
pitting as shown in Fig. 5. It illustrates this schematic localized corrosion mechanism of copper CMP in

Table 2

Summary of $\mathrm{pH}$, corrosion potentials $\left(E_{\text {corr }}\right)$, corrosion current densities $\left(i_{\text {corr }}\right)$, corrosion rates $(\mathrm{CR})$ and removal rates $(\mathrm{RR})$ of copper in $\mathrm{HNO}_{3}$ and $\mathrm{NH}_{4} \mathrm{OH}$ slurries

\footnotetext{
${ }^{\mathrm{a}}$ Abrasion at $34473.80 \mathrm{~N} / \mathrm{m}^{2}$ and $8.376 \mathrm{rad} / \mathrm{s}$.
} 


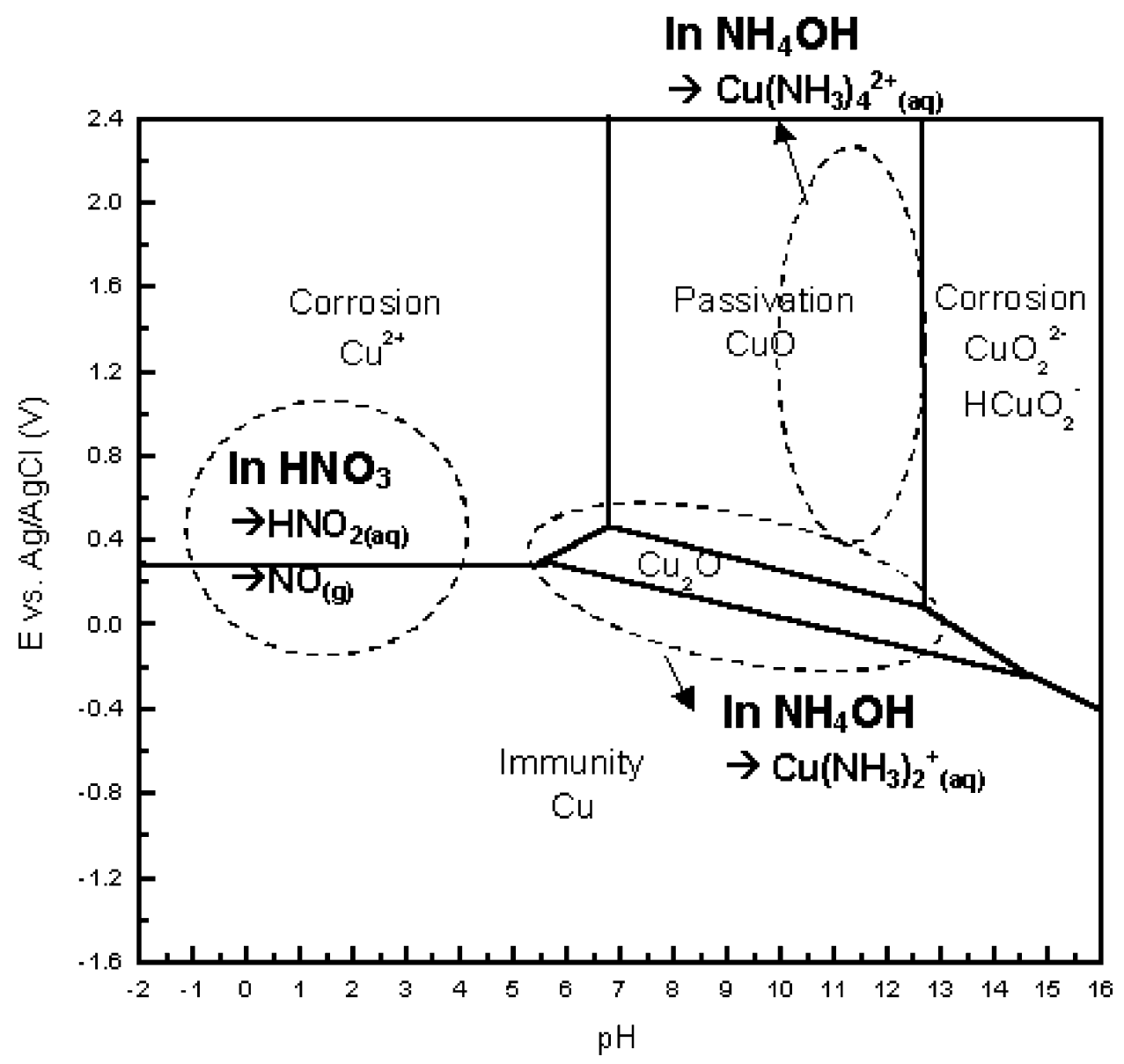

Fig. 4. Potential-pH equilibrium diagram for the system, copper-water, at $25^{\circ} \mathrm{C}$ [14]. The dash regions and the equilibrium components corresponding to the Pourbaix diagram in $\mathrm{HNO}_{3}$ and $\mathrm{NH}_{4} \mathrm{OH}$ solutions are shown $[14,15]$.

$\mathrm{HNO}_{3}$ slurries. Localized anodes are formed within pits produced by the polishing of the particles, and cathodes are formed on the surrounding surface to support the dissolution reaction of copper. If no protective films cover the copper surface to reduce the high corrosion rate, then the pitting propagation destroys the surface and deepens the pit so that the roughness is induced. Hence it was observed that the high corrosion rate worsens the smoothness of the copper surface in $\mathrm{HNO}_{3}$ slurries.

\subsection{2. $\mathrm{NH}_{4} \mathrm{OH}$ slurry}

Fig. 6 presents the potentiodynamic curves of copper in $\mathrm{NH}_{4} \mathrm{OH}$ slurries with no abrasion, and the corrosion parameters are listed in Table 2. As shown in Fig. 6, the anodic passive region is prominent.
Meantime, this passivation can effectively reduce the copper corrosion rate. Then the corresponding potentials and $\mathrm{pH}$ ranges are drawn on Fig. 4. It indicates that copper is expected to form an oxide film in an alkaline solution. When the $\mathrm{pH}$ falls in the range 7-13, the potential of $\mathrm{Cu}_{2} \mathrm{O}$ formation is low. However, $\mathrm{CuO}$ forms on copper at more positive potential. Therefore, the range listed in Table 2 reveals that the passive film should be $\mathrm{Cu}_{2} \mathrm{O}$ in $1-5 \mathrm{wt} . \%$ $\mathrm{NH}_{4} \mathrm{OH}$ solutions. On the other hand, for copper- $\mathrm{NH}_{3}$ system, the formation of stable copper-ammonia complex is rapid and the equilibrium components of Pourbaix diagram are illustrated in Fig. 4 $[14,15]$. Therefore, the anodic current density due to copper oxidation increases in spite of the passivation and the corrosion potential decreases with 


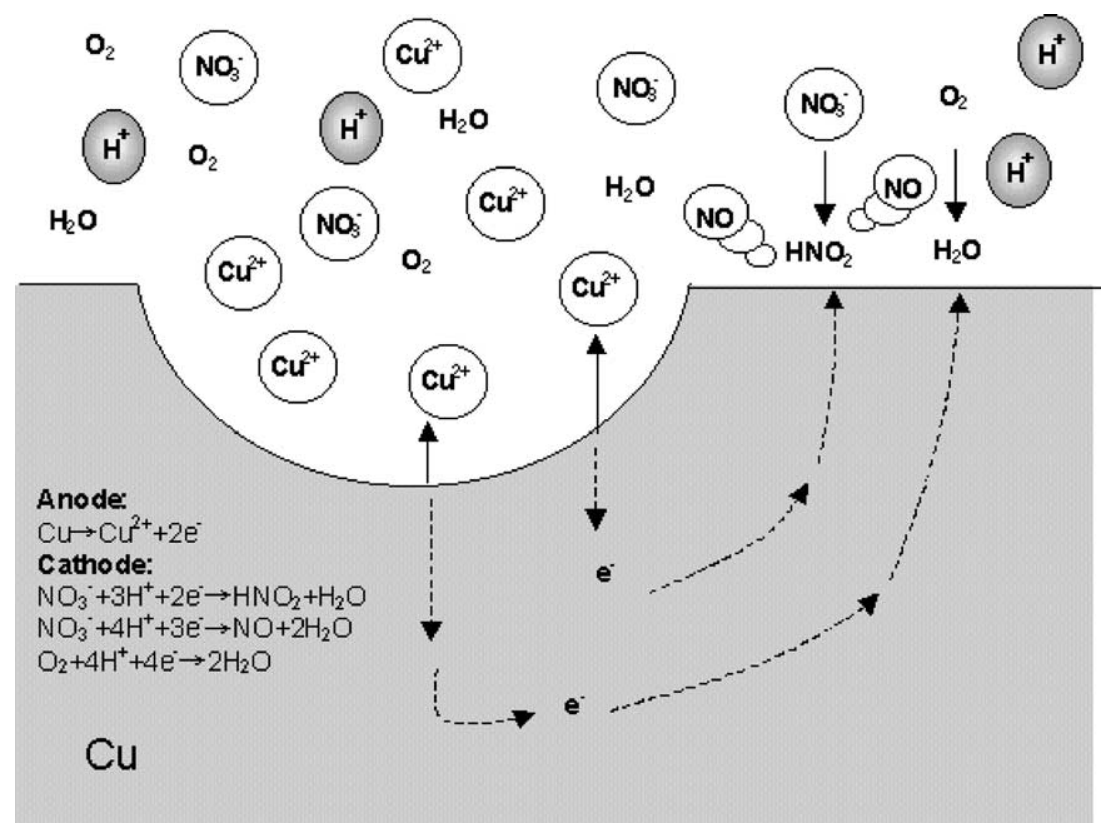

Fig. 5. The schematic localized corrosion mechanisms of copper $\mathrm{CMP}$ in $\mathrm{HNO}_{3}$-based slurries.

increasing $\mathrm{NH}_{4} \mathrm{OH}$ concentration. It can be deduced that the anodic current density increases because of the formation of stable copper-ammonia complex ion. The decreased corrosion potential reveals that the concentration of the copper ions is reduced according to the following Nernst relationship [13]:

$\Delta E \propto \ln a_{\mathrm{Cu}^{2+}}$

where $\Delta E$ is the difference in potential and standard potential of an electrode, and $a_{\mathrm{Cu}^{2+}}$ is the activity of $\mathrm{Cu}^{2+}$. The decreased corrosion potential also means that the copper-ammonia complex ion forms in the solution instead of $\mathrm{Cu}^{2+}$. Therefore the un-complex copper ion reduces with increasing $\mathrm{NH}_{4} \mathrm{OH}$ concentration, and the corrosion potential is also decreased.

To sum up, the electrochemical reactions of copper CMP in $\mathrm{NH}_{4} \mathrm{OH}$-based slurries can be described as follows:

Anode:

$2 \mathrm{Cu}+\mathrm{H}_{2} \mathrm{O} \rightarrow \mathrm{Cu}_{2} \mathrm{O}+2 \mathrm{H}^{+}+2 \mathrm{e}^{-}$,

$E^{0}=0.471 \mathrm{~V}$

$\mathrm{Cu}_{2} \mathrm{O}+2 \mathrm{H}^{+} \rightarrow 2 \mathrm{Cu}^{2+}+\mathrm{H}_{2} \mathrm{O}+2 \mathrm{e}^{-}$,

$E^{0}=0.203 \mathrm{~V}$
Reaction and complex:

$\mathrm{Cu}^{2+}+4 \mathrm{NH}_{3} \rightarrow \mathrm{Cu}\left(\mathrm{NH}_{3}\right)_{4}{ }^{2+}$

$\mathrm{Cu}_{2} \mathrm{O}+2 \mathrm{H}^{+}+2 \mathrm{NH}_{3} \rightarrow 2 \mathrm{Cu}\left(\mathrm{NH}_{3}\right)_{2}{ }^{+}+\mathrm{H}_{2} \mathrm{O}$

Cathode:

$\mathrm{Cu}^{2+}+2 \mathrm{NH}_{3}+\mathrm{e}^{-} \rightarrow \mathrm{Cu}\left(\mathrm{NH}_{3}\right)_{2}{ }^{+}$,

$E^{0}=0.457 \mathrm{~V}$

$\mathrm{O}_{2}+2 \mathrm{H}_{2} \mathrm{O}+4 \mathrm{e}^{-} \rightarrow 4 \mathrm{OH}^{-}$,

$E^{0}=0.401 \mathrm{~V}$

Fig. 7 illustrates the schematic localized corrosion mechanisms of copper $\mathrm{CMP}$ in $\mathrm{NH}_{4} \mathrm{OH}$-based slurries. On the convex areas, the oxide film is mechanically abraded from the surface, and the dislodged materials are then dissolved by complex reactions. However, the oxide film can cover recessed areas and protect the underlying copper. Thus, the re-exposed copper region receives less mechanical abrasion, in comparison with the un-breakdown passive film, and then this region would be re-passivated. Due to this situation, the pitting propagation is inhibited. Then above-mentioned actions could be applied to each point of copper surface uniformly to produce global planarization. 


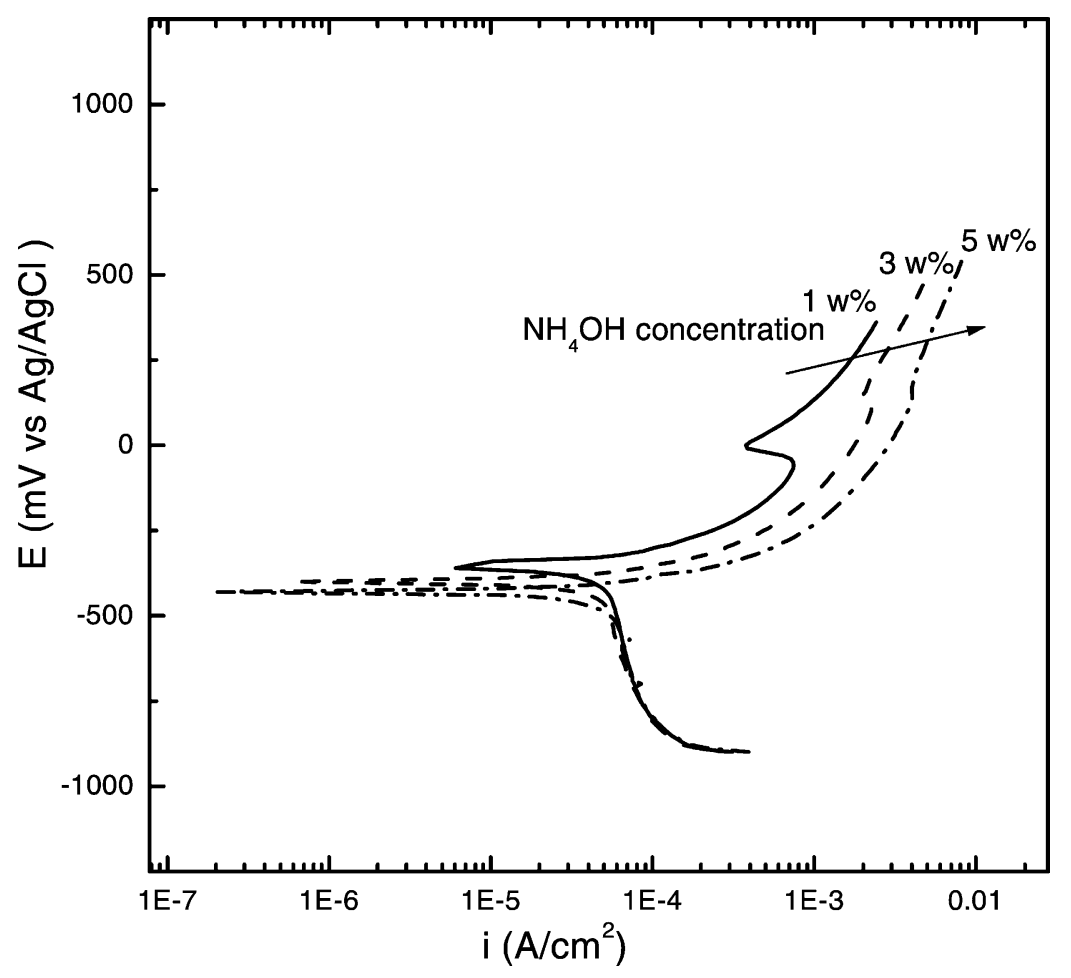

Fig. 6. Potentiodynamic curves of copper in the slurries of various $\mathrm{NH}_{4} \mathrm{OH}$ concentrations without abrasion.

The CMP results of $\mathrm{NH}_{4} \mathrm{OH}$ slurries, listed in Table 2, indicate that all of the removal rates and corrosion rates in $\mathrm{NH}_{4} \mathrm{OH}$ slurries are lower than those in $\mathrm{HNO}_{3}$ slurries owing to the formation of passive films. Hence, the $\mathrm{NH}_{4} \mathrm{OH}$-based slurries with low corrosion rate can perform better than $\mathrm{HNO}_{3}$-based slurries from the perspective of planarization. As mentioned above, the reactions of chelating copper ions are expected to increase corrosion rates, while the passive reactions decrease the corrosion rate. However, the corrosion rate obtained from our experiments does not increase obviously with increasing $\mathrm{NH}_{4} \mathrm{OH}$ concentrations. As a result, the removal rate is still so low in $\mathrm{NH}_{4} \mathrm{OH}$ slurries that the throughput of CMP is limited. Thus, it should be concluded the rate-determining step among the mechanisms of copper in $\mathrm{NH}_{4} \mathrm{OH}$ slurries is the oxidation reaction of the copper surface film but chelating reactions. In addition, the slow formation rate and the rapid chelating rate of passive films induce the pitting propagation in the breakdown region before initiating another breakdown of passive film. Therefore, the removal rate of copper
CMP needs to be enhanced by adding an oxidant, such as $\mathrm{KNO}_{3}$, to $\mathrm{NH}_{4} \mathrm{OH}$-based slurries so that the copper oxidation can be accelerated.

\subsection{Corrosion modifications of acidic and alkaline slurries}

Since the over high dissolution rate worsen the smoothness of the copper surface in acidic $\mathrm{HNO}_{3}$ slurries and the over low removal rate limits the application for the need of high throughput in alkaline $\mathrm{NH}_{4} \mathrm{OH}$ slurries, some modifications of corrosion effects to apply the acidic and alkaline slurries are required.

\subsubsection{Dissolution modification}

As mentioned above, the alumina slurry needs to be maintained in either acidic or alkaline surroundings. Meanwhile, it is considered to reduce the corrosion rate in acidic $\mathrm{HNO}_{3}$ slurries. So a well-known oxide resist for copper, benzotriazole (BTA), has thus been adopted herein as an additive to the slurries. 


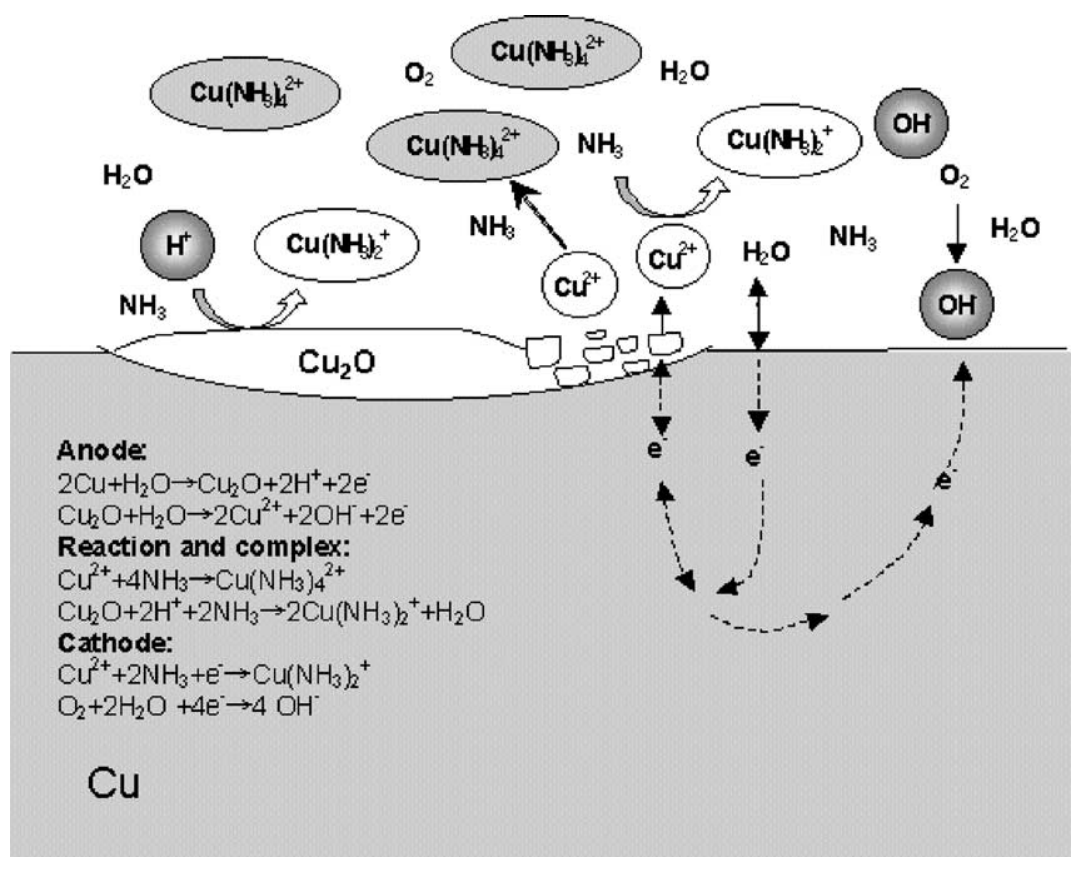

Fig. 7. The schematic localized corrosion mechanisms for copper $\mathrm{CMP}$ in $\mathrm{NH}_{4} \mathrm{OH}$-based slurries.

The modified effects of adding BTA are presented in Fig. 8. Increase in corrosion rates with $\mathrm{HNO}_{3}$ concentrations indicate once again that no passive film is formed on the copper surface. In addition, Fig. 8 reveals that the corrosion rate in $5 \mathrm{wt} \% \mathrm{HNO}_{3}$ declined two orders of magnitude after $0.1 \mathrm{wt} . \%$ BTA was added. The copper surface is thus clearly anti-corroded by the BTA. It shows that the adding of an inhibitor, BTA, can form an adsorbed BTA of nonnative film on copper surface (Cu-BTA film) and this non-native film can protect copper against pitting propagation. Furthermore, the dependence of copper corrosion rates on BTA concentrations in $5 \mathrm{wt} . \%$ $\mathrm{HNO}_{3}$ solution is also displayed in Fig. 8 (top axis). It is obvious that copper corrosion rate decreased with increasing BTA concentrations. However, the nonnative passive effect of BTA was weakened when the BTA concentrations exceed 0.1 in 5 wt. $\% \mathrm{HNO}_{3}$ slurries. It seems that the adsorption of $0.1 \mathrm{wt} . \% \mathrm{BTA}$ on a $0.197 \mathrm{~cm}^{2}$ copper surface is saturated. Moreover, to investigate the effect of BTA on the polishing, potentiodynamic measurements were conducted in 5 wt. $\% \mathrm{HNO}_{3}$ slurries, and their potentiodynamic curves were presented in Fig. 9. From the figure, adding $0.1 \mathrm{wt} . \%$ BTA produces a significant difference in corrosion potential $\left(\Delta E_{\mathrm{d}}\right)$ between abrasion and no abrasion, 145.8 and $0.1 \mathrm{mV}$, respectively, listed in Table 3. Nevertheless, this difference, on the contrary, would not been observed from the curves without BTA. Hence, this difference can be explained by the sensibility of surface for the abrasion. When $0.1 \mathrm{wt}$ \% BTA is added, the Cu-BTA film is formed stably on the surface with no abrasion, and the corrosion potential approached near to zero. However, $\mathrm{Cu}$-BTA film is removed from copper with abrasion to create a corrosion interface of copper and $\mathrm{HNO}_{3}$, so the reaction potential is higher. As observed, the corrosion potential in the electrochemical measurements varied with the mechanical polishing, but that did not occur when no BTA is added, i.e. in only 5 wt.\% $\mathrm{HNO}_{3}$ slurries. This phenomenon suggests that BTA can effectively protect the recessed areas from undesired copper pitting propagation and can be included in the acidic slurries of copper CMP, such as $\mathrm{HNO}_{3}$-based slurries.

\subsubsection{Oxidization modifications}

Corrosion effects of alkaline slurries require to be modified from the view of enhancing oxidation rate of copper as mentioned before. Potassium nitrate is a 


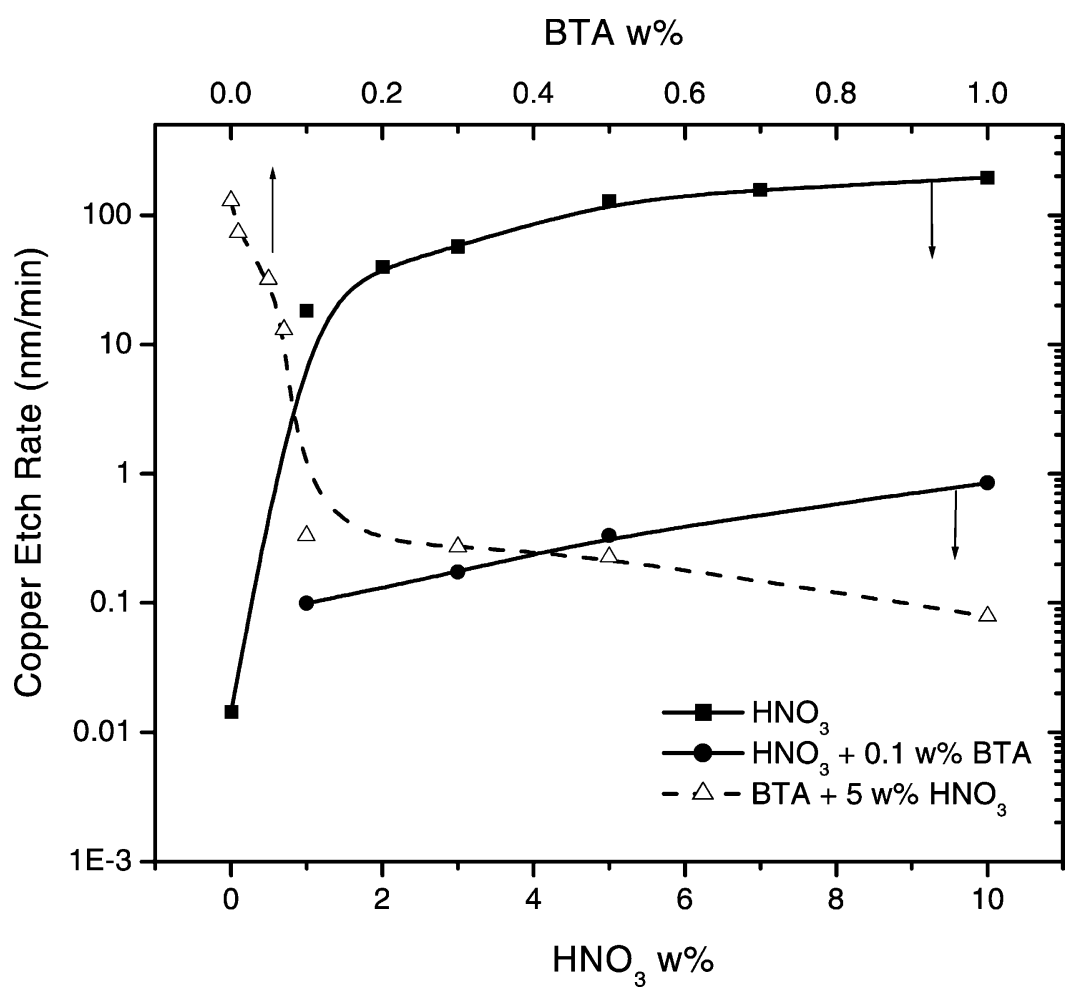

Fig. 8. Copper corrosion rates versus $\mathrm{HNO}_{3}$ concentrations (bottom axis) with and without 0.1 wt.\% BTA concentrations (top axis) in $5 \mathrm{wt} \% \mathrm{HNO}_{3}$ solutions $(\triangle)$.

strong oxidizer owing to the oxidation power of nitrate, and thus can be considered to add into alkaline slurries. Moreover, the $\mathrm{pH}$ of slurries would not be varied with the added $\mathrm{KNO}_{3}$, so the dispersion of alumina abrasives can be maintained. Fig. 10 displays all of the potentiodynamic curves, including $5 \mathrm{wt} . \%$ $\mathrm{KNO}_{3}, 5$ wt. $\% \mathrm{KNO}_{3}+1$ wt. $\% \mathrm{NH}_{4} \mathrm{OH}$ and 1 wt. $\%$ $\mathrm{NH}_{4} \mathrm{OH}$ slurries and the corrosion parameters are summarized in Table 3. In comparison with these curves of abrasion and no abrasion, it reveals that the anodic passive regions of potentiodynamic curves are quite prominent when measured without abrasion, indicating that passive actions exist on copper surfaces no matter in 5 wt. $\% \mathrm{KNO}_{3}, 5$ wt. $\% \mathrm{KNO}_{3}+1$ wt. $\%$ $\mathrm{NH}_{4} \mathrm{OH}$ or $1 \mathrm{wt} \% \mathrm{NH}_{4} \mathrm{OH}$ slurries. Among these curves of Fig. 10, the potentiodynamic curves for

Table 3

Summary of corrosion potentials, corrosion current densities and the drop of corrosion potentials with abrasion $\left(\Delta E_{\mathrm{d}}\right)$ of copper in various slurries

\begin{tabular}{|c|c|c|c|c|c|}
\hline \multirow[t]{2}{*}{ Slurry } & \multicolumn{2}{|c|}{$E_{\text {corr }}(\mathrm{mV})$ vs. $\mathrm{Ag} / \mathrm{AgCl}$} & \multicolumn{2}{|l|}{$i_{\text {corr }}\left(\mathrm{A} / \mathrm{cm}^{2}\right)$} & \multirow[t]{2}{*}{$\Delta E_{\mathrm{d}}^{\mathrm{a}}(\mathrm{mV})$} \\
\hline & No abrasion & Abrasion & No abrasion & Abrasion & \\
\hline 5 wt. $\% \mathrm{HNO}_{3}$ & 119.3 & 119.0 & $5.8 \times 10^{-3}$ & $1.7 \times 10^{-3}$ & 0.3 \\
\hline 5 wt. $\% \mathrm{HNO}_{3}+0.1$ wt. $\%$ BTA & 0.1 & 145.8 & $3.7 \times 10^{-6}$ & $1.5 \times 10^{-5}$ & -145.7 \\
\hline 5 wt. $\% \mathrm{KNO}_{3}$ & -4.9 & -180.5 & $5.3 \times 10^{-6}$ & $7.9 \times 10^{-6}$ & 175.6 \\
\hline 1 wt. $\% \mathrm{NH}_{4} \mathrm{OH}$ & -370.1 & -410.2 & $5.6 \times 10^{-5}$ & $6.5 \times 10^{-6}$ & 40.1 \\
\hline 5 wt. $\% \mathrm{KNO}_{3}+1$ wt. $\% \mathrm{NH}_{4} \mathrm{OH}$ & -385.9 & 422.1 & $1.2 \times 10^{-5}$ & $3.4 \times 10^{-5}$ & 36.2 \\
\hline
\end{tabular}

\footnotetext{
${ }^{\text {a }} \Delta E_{\mathrm{d}}=E_{\text {corr(no abrasion) }}-E_{\text {corr(abrasion) }}$.
} 


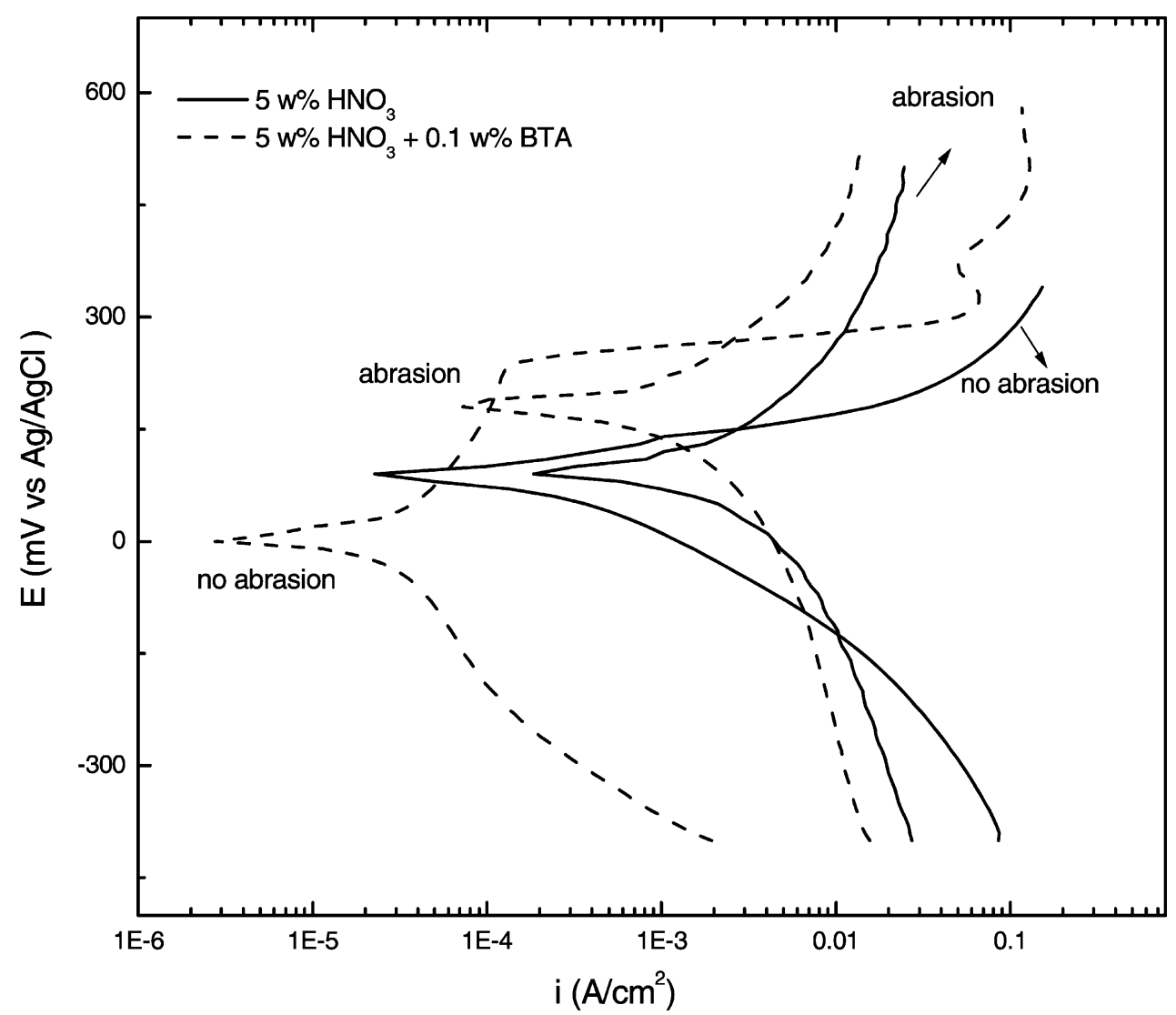

Fig. 9. Potentiodynamic curves of copper in 5 wt. $\% \mathrm{HNO}_{3}$ and 5 wt. $\% \mathrm{HNO}_{3}+0.1$ wt. $\%$ BTA slurries with no abrasion and abrasion $\left(34473.80 \mathrm{~N} / \mathrm{m}^{2} / 8.376 \mathrm{rad} / \mathrm{s}\right)$.

the 5 wt. $\% \mathrm{KNO}_{3}$ slurries have the largest drop of corrosion potentials with abrasion $\left(\Delta E_{\mathrm{d}}\right)$; meanwhile, an increment in the corrosion current density occurs for the abraded sample. This phenomenon indicates that the strong oxidization of copper surface results in the formation of copper oxide in $5 \mathrm{wt} . \% \mathrm{KNO}_{3}$ slurries. Therefore, the corrosion reaction takes place at higher potential with no abrasion. When fresh copper surface is exposed again to the $5 \mathrm{wt} . \% \mathrm{KNO}_{3}$ slurry by removing passive films with abrasion, the copper could be oxidized progressively at lower potential. As adding 5 wt. $\% \mathrm{KNO}_{3}$ into 1 wt. $\% \mathrm{NH}_{4} \mathrm{OH}$, the drop of corrosion potentials with abrasion $\left(\Delta E_{\mathrm{d}}\right)$ is lessened to $36.2 \mathrm{mV}$ as listed in Table 3 . This value approached to $\Delta E_{\mathrm{d}}$ in $1 \mathrm{wt} . \% \mathrm{NH}_{4} \mathrm{OH}$ slurry. It reveals that chemical complexation as well as mechanical polishing achieves the removal of passive films. When $\mathrm{NH}_{4} \mathrm{OH}$ is added during copper CMP, complexation by $\mathrm{NH}_{3}$ helps to dissolve the passive film and dislodged materials. The corrosion potential is thus less sensitive to abrasion, and less difference in potentials could be observed in $\mathrm{KNO}_{3}-\mathrm{NH}_{4} \mathrm{OH}$ slurries.

Table 4 lists the experimental polishing results from several slurries. A high removal rate, which is equivalent to high process throughput, is always essential for CMP, but a high corrosion rate is generally not acceptable due to the induced surface roughness. The ratio of removal rate to corrosion rate is defined as the CMP efficiency factor. Hence, a high CMPEF means high mechanical removal ability and a well planarity. However, usual slurry has two conflicting functions in the mechanism of metal CMP: one is to dissolve materials dislodged from the surface and carry them away to avoid re-deposition, while the other is to assure planarity by forming a surface film to avoid the pitting propagation of breakdown areas on the surface. 


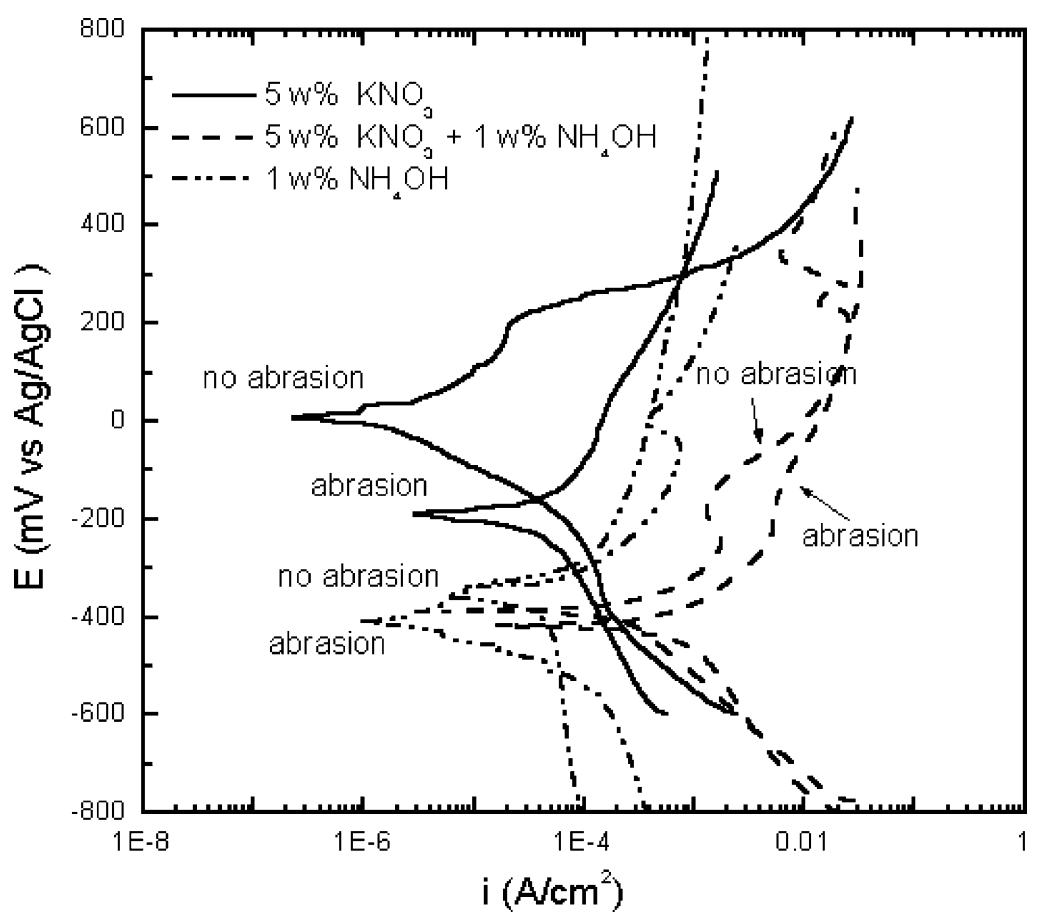

Fig. 10. Potentiodynamic curves of copper in 5 wt. $\% \mathrm{KNO}_{3}, 5$ wt. $\% \mathrm{KNO}_{3}+1$ wt. $\% \mathrm{NH}_{4} \mathrm{OH}$ and 1 wt. $\% \mathrm{NH}_{4} \mathrm{OH}$ slurries with no abrasion and abrasion $\left(34473.80 \mathrm{~N} / \mathrm{m}^{2} / 8.376 \mathrm{rad} / \mathrm{s}\right)$.

As a result, both high removal rate and high CMPEF must be achieved herein. As presented in Table 4, CMPEFin $5 \mathrm{wt} \% \mathrm{KNO}_{3}$ is high enough, but the removal rate in $5 \mathrm{wt} . \% \mathrm{KNO}_{3}(253 \mathrm{~nm} / \mathrm{min})$ is so low that $\mathrm{KNO}_{3}$ slurry has limited applications for the copper CMP process. The measured results also show that the oxidizer $5 \mathrm{wt} . \% \mathrm{KNO}_{3}$ can significantly increase the removal rate from $253 \mathrm{~nm} / \mathrm{min}$ in the absence of $\mathrm{NH}_{4} \mathrm{OH}$, to $360 \mathrm{~nm} / \mathrm{min}$ with $1 \mathrm{wt} . \% \mathrm{NH}_{4} \mathrm{OH}$ added. Furthermore, although all the cases of $\mathrm{HNO}_{3}$-based slurries have higher removal rates according to Table 4, CMPEF in pure $\mathrm{HNO}_{3}$ slurry is so low that the pitting propagation cannot be inhibited to make appropriate slurry for copper. Therefore, in view of higher CMPEF and higher RR, pure $\mathrm{HNO}_{3}$, pure $\mathrm{KNO}_{3}$ or pure $\mathrm{NH}_{4} \mathrm{OH}$ slurry is not suitable for copper CMP, but the modified slurries can improve their performances.

\subsection{Corrosion effects on mechanical action}

The mechanical action is also controlled by corrosion behaviors between copper and slurries. It is

Table 4

Removal rates (RR), corrosion rates (CR), their ratios (CMPEF), the average value of $\mathrm{dRR} / \mathrm{d} P$ and the surface roughness $\left(R_{\mathrm{q}}\right)$ of copper for CMP with various slurries at $34473.80 \mathrm{~N} / \mathrm{m}^{2}$ and $8.376 \mathrm{rad} / \mathrm{s}$

\begin{tabular}{|c|c|c|c|c|c|}
\hline Solution & $\mathrm{RR}(\mathrm{nm} / \mathrm{min})$ & $\mathrm{CR}(\mathrm{nm} / \mathrm{min})$ & $\mathrm{CMPFE}^{\mathrm{a}}$ & $\mathrm{dRR} / \mathrm{d} P$ & $R_{\mathrm{q}}(\mathrm{nm})$ \\
\hline $\mathrm{H}_{2} \mathrm{O}$ & 73.6 & 0.014 & $5.26 \times 10^{3}$ & - & 29.345 \\
\hline 5 wt. $\% \mathrm{HNO}_{3}$ & 589 & 37.48 & $1.51 \times 10^{1}$ & 8.0 & 32.024 \\
\hline 5 wt. $\% \mathrm{HNO}_{3}+0.1$ wt. $\%$ BTA & 484 & 0.332 & $1.46 \times 10^{3}$ & 17.5 & 4.019 \\
\hline 1 wt. $\% \mathrm{KNO}_{3}$ & 253 & 0.174 & $1.45 \times 10^{3}$ & - & - \\
\hline 1 wt. $\% \mathrm{NH}_{4} \mathrm{OH}$ & 275 & 0.140 & $1.96 \times 10^{3}$ & 4.4 & 14.791 \\
\hline 5 wt. $\% \mathrm{KNO}_{3}+1$ wt. $\% \mathrm{NH}_{4} \mathrm{OH}$ & 360 & 0.742 & $4.86 \times 10^{2}$ & 9.9 & 3.971 \\
\hline
\end{tabular}

\footnotetext{
${ }^{\mathrm{a}} \mathrm{CMPEF}=\mathrm{RR} / \mathrm{CR}$.
} 
known that the simplest relation describing the mechanical action of copper polishing is the Preston equation [16], namely the removal rate is directly proportional to the polishing pressure and the relative speed. Herein, the removal rate is a function of both downward force and relative rotating speed, as displayed in Fig. 11, for various slurries. Combined with the corrosion mechanisms above, this relation may be used to explain the removal condition on copper surfaces. For a constant rotation speed, the removal

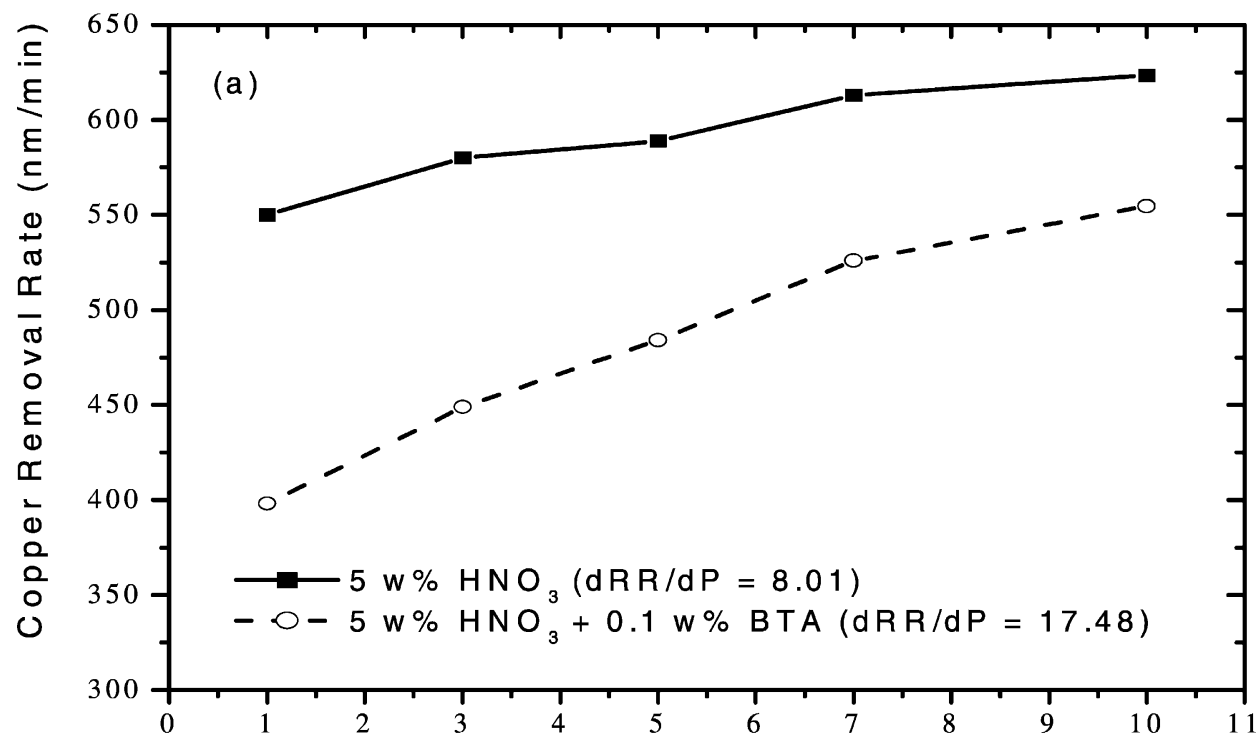

(a)

\section{Pressure (psi)}

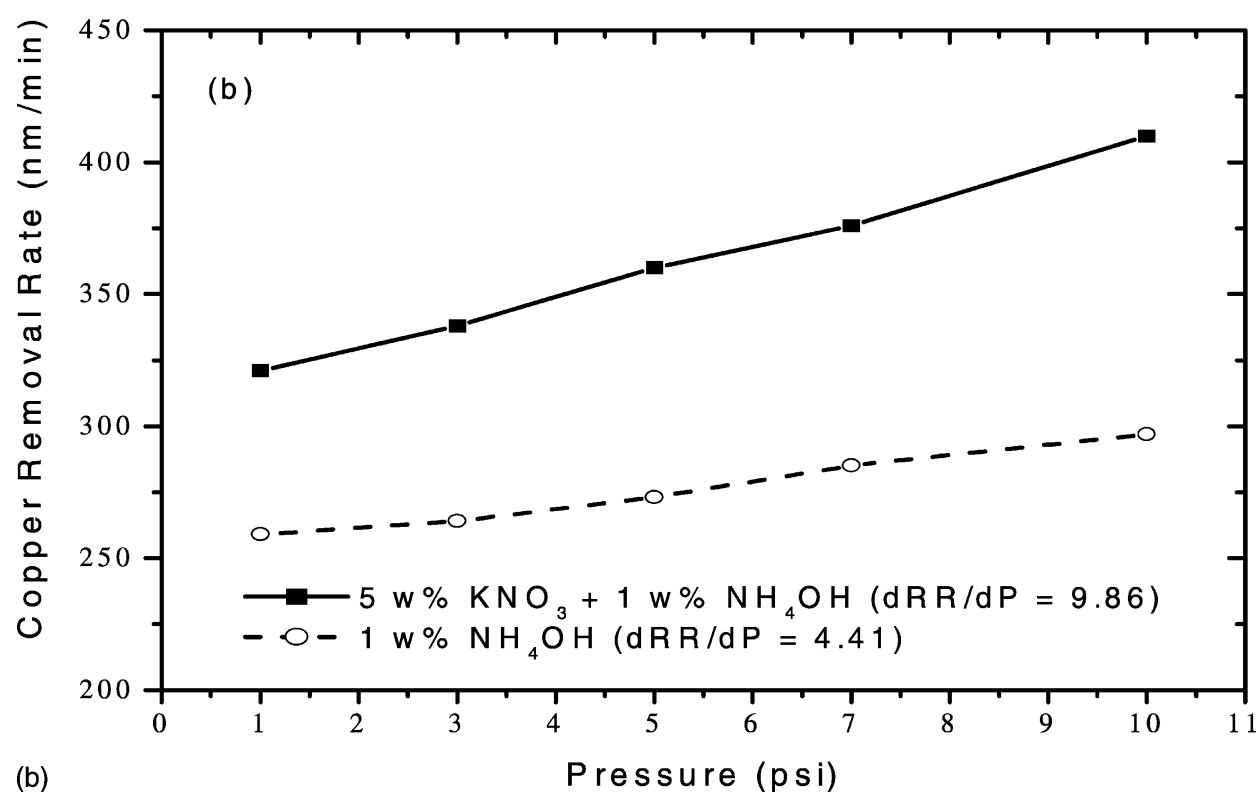

Fig. 11. Copper removal rates versus pressures at $8.376 \mathrm{rad} / \mathrm{s}$ in various slurries: (a) $5 \mathrm{wt} . \% \mathrm{HNO}_{3}$ and $5 \mathrm{wt} . \% \mathrm{HNO}+0.1 \mathrm{wt} \% \mathrm{BTA}$ slurries; (b) 5 wt. $\% \mathrm{KNO}_{3}+1$ wt. $\% \mathrm{NH}_{4} \mathrm{OH}$ and 1 wt. $\% \mathrm{NH}_{4} \mathrm{OH}$ slurries. 
rate mainly relies on the polishing pressure $(P)$, and its dependency can be described by the differentiation of RR with respect to the $P, \mathrm{dRR} / \mathrm{d} P$, as listed in Table 4 . It indicates that the measured results of $\mathrm{dRR} / \mathrm{d} P$ in 5 wt. $\% \mathrm{HNO}_{3}+0.1 \mathrm{wt} . \%$ BTA (17.5) and $5 \mathrm{wt} . \%$ $\mathrm{KNO}_{3}+1 \mathrm{wt} . \% \mathrm{NH}_{4} \mathrm{OH}(9.9)$ slurries are higher than those in 5 wt. $\% \mathrm{HNO}_{3}(8.0)$ and 1 wt. $\% \mathrm{NH}_{4} \mathrm{OH}(4.4)$, respectively, found from Fig. 11a and $\mathrm{b}$ and listed in Table 4. The higher $\mathrm{dRR} / \mathrm{d} P$ indicates that more passive films are removed, that is, more films are formed on copper surfaces by the chemical adsorption of BTA or oxidation by nitrate. Meanwhile, higher (a) $\mathrm{Rq}=62.397 \mathrm{~nm}$

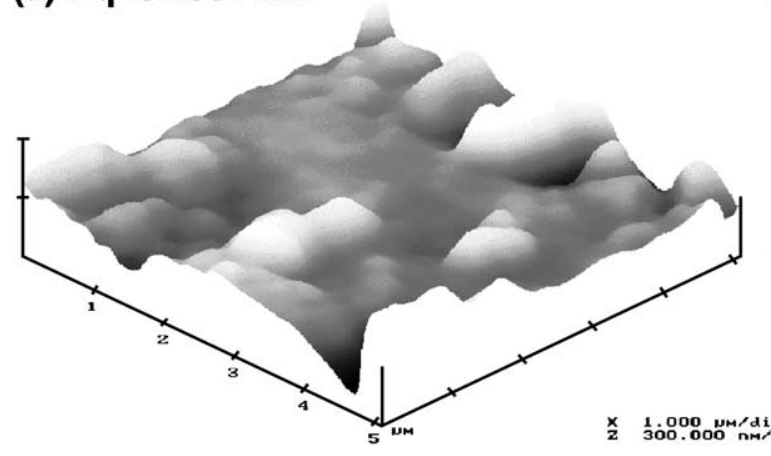

(b) $R q=29.345 \mathrm{~nm}$

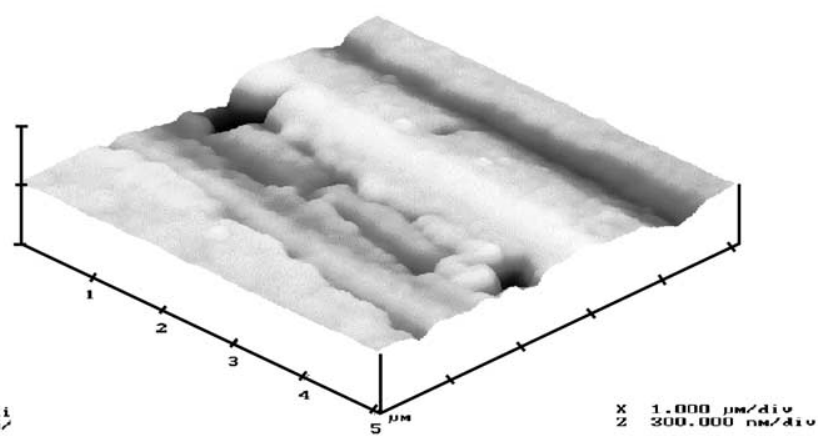

(c) $\mathrm{Rq}=32.024 \mathrm{~nm}$

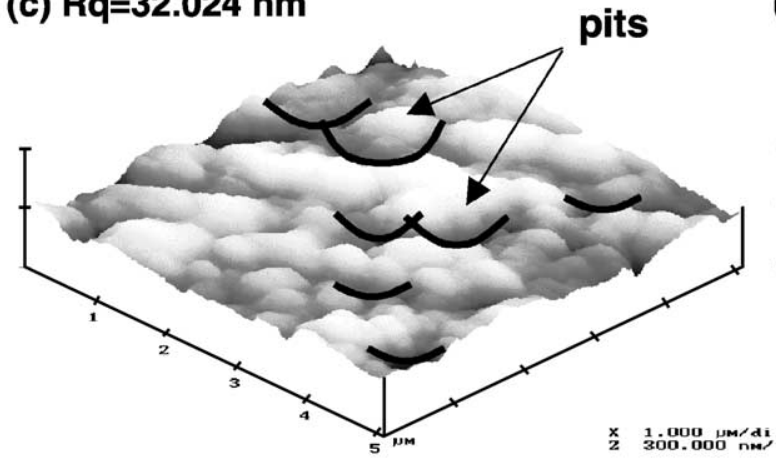

(d) $\mathrm{Rq}=4.019 \mathrm{~nm}$

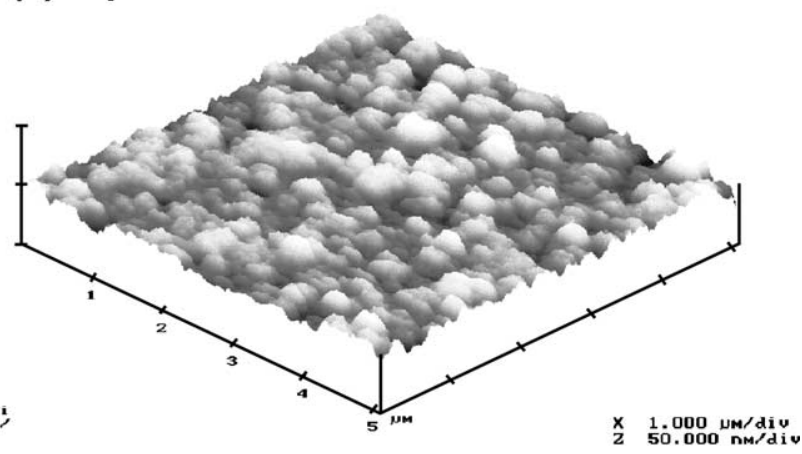

(e) $R q=14.791 \mathrm{~nm}$

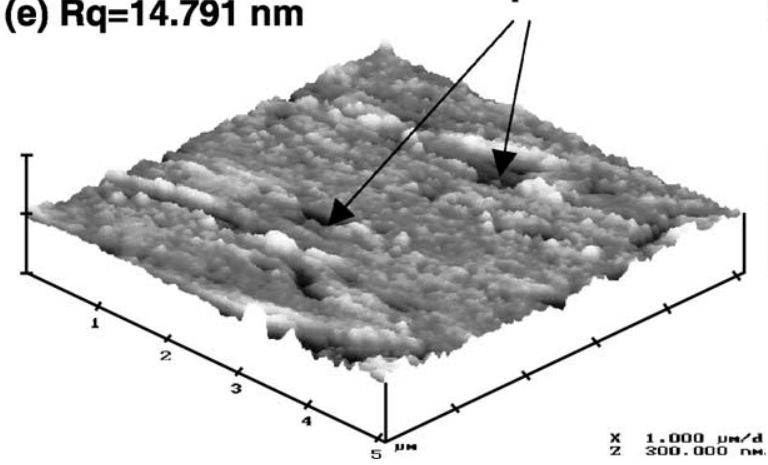

(f) $\mathrm{Rq}=3.971 \mathrm{~nm}$

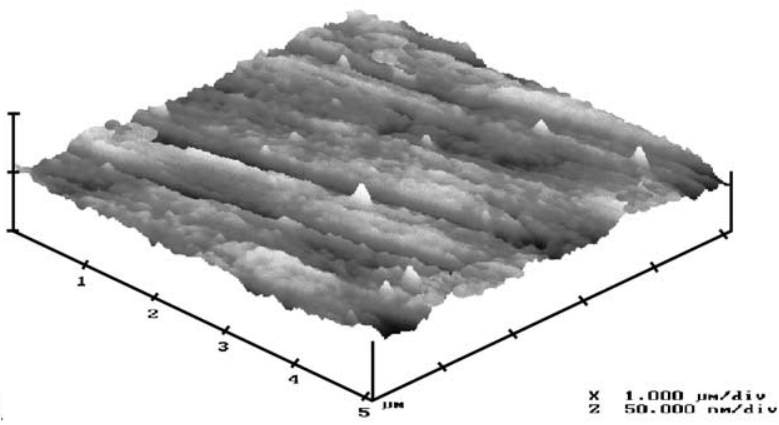

Fig. 12. AFM micrographs showing the morphology of copper surface: (a) before polishing and after polishing in slurries of (b) DIW, (c) 5 wt. $\% \mathrm{HNO}_{3}$, (d) 5 wt. $\% \mathrm{HNO}_{3}+0.1$ wt. $\% \mathrm{BTA}$, (e) 1 wt. $\% \mathrm{NH}_{4} \mathrm{OH}$ and (f) 5 wt. $\% \mathrm{KNO}_{3}+1$ wt. $\% \mathrm{NH}_{4} \mathrm{OH}$. 
$\mathrm{dRR} / \mathrm{d} P$ also means the removal mechanisms are sensitive to mechanical polishing, representing higher CMPEF and better planarity. The results of $\mathrm{dRR} / \mathrm{d} P$ in Table 4 indicate that BTA or $\mathrm{KNO}_{3}$ has a good ability to passivate copper surfaces and protect copper from pitting propagation.

\subsection{Surface morphology of copper}

Fig. 12 show the AFM micrographs of copper surfaces before and after CMP with various slurries and the average surface roughness is listed in Table 4. Before CMP, the image of the copper surface with the calculated surface roughness, $62.379 \mathrm{~nm}$, for the scan size $5 \mu \mathrm{m} \times 5 \mu \mathrm{m}$ is shown in Fig. 12a. Then the roughness was reduced to $29.345 \mathrm{~nm}$ after CMP using only 5 wt. $\% \alpha-\mathrm{Al}_{2} \mathrm{O}_{3}$ aqueous slurries without adding any other chemical reagent. However, the surface roughness as shown in Fig. 12c is increased contrarily after CMP using $5 \mathrm{wt} . \% \mathrm{HNO}_{3}$ without any corrosion modifications. It indicates that serious dissolution on copper surface results in depth pitting corrosion, and the pitting propagation for copper proceeds to destroy the planarization. Thus, the pits of copper surface are obvious as indicated in Fig. 12c. As 0.1 wt.\% BTA was added into 5 wt. $\% \mathrm{HNO}_{3}$ slurries, shown in Fig. 12d, it can be seen that the polished copper surface appears relatively smooth, and what is more, the surface roughness decreases from 32.024 to $4.019 \mathrm{~nm}$. On the other hand, after copper CMP using $1 \mathrm{wt} . \%$ $\mathrm{NH}_{4} \mathrm{OH}$ slurry, the surface roughness decreases to $14.791 \mathrm{~nm}$ that is lower than it in $5 \mathrm{wt} \% \mathrm{HNO}_{3}$ slurries. Several smaller pits of copper surface, however, are still found as indicated in Fig. 12d. Above results respond to the mechanisms of pitting corrosion as described in Figs. 6 and 7, i.e. the pitting propagation of breakdown regions may occur in $\mathrm{HNO}_{3}$ and $\mathrm{NH}_{4} \mathrm{OH}$ slurries. Furthermore, the surface roughness is the lowest after CMP using 5 wt. $\% \mathrm{KNO}_{3}+1$ wt. $\%$ $\mathrm{NH}_{4} \mathrm{OH}$ slurry. All of the AFM results are consistent with above corrosion actions. As was noted previously, different corrosion modifications of acidic and alkaline can enhance the CMP performance and achieve better planarization. Thus, it is supposed that copper CMP using $5 \mathrm{wt} . \% \mathrm{HNO}_{3}$ with the dissolution modification by adding $0.1 \mathrm{wt} . \%$ BTA or $1 \mathrm{wt} . \%$ $\mathrm{NH}_{4} \mathrm{OH}$ with the oxidization modification by adding 1 wt. $\% \mathrm{KNO}_{3}$ can provide a smooth and homogeneous surface, which is well adequate for delineating copper patterns in the deep sub-micron integrated circuits.

\section{Conclusion}

In acidic $\mathrm{pH}<4.56$ and alkaline $\mathrm{pH}>9.05$ slurries, the copper always had the same charge with $\alpha$ $\mathrm{Al}_{2} \mathrm{O}_{3}$ and $\mathrm{Cu}_{2} \mathrm{O}$. Thus, the contamination of residual particles on the copper surface is minimized and the dispersion of $\alpha-\mathrm{Al}_{2} \mathrm{O}_{3}$ particles in slurries is improved for these $\mathrm{pH}$ ranges. The surface layer of copper experiences, however, pitting initiation and propagation in $\mathrm{HNO}_{3}$ and $\mathrm{NH}_{4} \mathrm{OH}$ slurries. These phenomena would worsen the planarization. Thus, some corrosion modifications are required to enhance the CMP efficiency. In a general copper CMP process, both removal rate and CMPEF must be high. The addition of 0.1 wt.\% BTA modifies 5 wt. $\% \mathrm{HNO}_{3}$ slurries to achieve effective corrosion inhibition for copper films and to obtain a high CMPEF. On the other hand, adding an extra oxidizer, $\mathrm{KNO}_{3}$, modifies $5 \mathrm{wt} \%$ $\mathrm{NH}_{4} \mathrm{OH}$ to increase the copper anodic oxidation on the copper surface, and to accelerate the removal rate as well as the CMPEF. Moreover, the higher slopes of removal rate vs. pressure $(\mathrm{dRR} / \mathrm{d} P)$ for $5 \mathrm{wt} . \% \mathrm{HNO}_{3}$ +0.1 wt. $\%$ BTA and 5 wt. $\% \mathrm{KNO}_{3}+1$ wt. $\% \mathrm{NH}_{4} \mathrm{OH}$ slurries indicate that corrosion modifications can enhance the surface sensitivity to mechanical polishing, i.e. CMPEF. Above all, corrosion measurements and pitting mechanisms used herein are the most viable means of evaluating the performance of slurries and the direction of modifications for metal CMP.

\section{Acknowledgements}

The authors thank the National Science Council of Taiwan, Republic of China, for financially supporting this research under Contract no. NSC 89-2214-E-002030 .

\section{References}

[1] D. Edelstein, J. Heidenreich, R. Goldblatt, W. Cote, C. Uzoh, N. Lustig, P. Roper, T. McDevitt, W. Motsiff, A. Simon, J. Dukovic, R. Wachnik, H. Rathore, R. Schulz, S. Su, S. Luce, J. Diggest, in: Proceedings of the International Conference 
IEEE International Electronic Devices Meeting, Washington, DC, 1997, p. 773.

[2] M.T. Wang, W.K. Yeh, M.S. Tsai, W.T. Tseng, T.C. Chang, M.C. Chen, Mater. Chem. Phys. 51 (1997) 75-79.

[3] F.B. Kaufman, D.B. Thompson, R.E. Broadie, M.A. Jaso, W.L. Guthrie, D.J. Pearson, M.B. Small, J. Electrochem. Soc. 138 (11) (1991) 3460-3465.

[4] Y. Gotkis, S. Alamgir, L. Yang, F. Dai, F. Mitchell, J. Nguyen, L. Shumway, L.R. Walesa, J. Yang, P. Nunan, K. Holland, J. Vacuum Soc. Technol. B 17 (5) (1999) 2269-2271.

[5] P. Wrschka, J. Hernandez, G.S. Oehrlein, J.A. Negrych, G. Haag, P. Rat, J.E. Currie, J. Electrochem. Soc. 148 (6) (2001) G321-G325.

[6] Y. Li, S.V. Babu, Electrochem. Solid-State Lett. 4 (2) (2001) G20-G22.

[7] H.G. Kim, Y.M. An, D.K. Moon, J.G. Park, Jpn. J. Appl. Phys. 39 (1) 3A (2000) 1085-1090.
[8] W.C. Chen, C.T. Yen, J. Vacuum Soc. Technol. B 18 (1) (2000) 201-207.

[9] S. Kondo, N. Sakuma, Y. Homma, N. Ohashi, Jpn. J. Appl. Phys. 39 (1) 11 (2000) 6216-6222.

[10] M. Bielmann, U. Mahajan, R.K. Singh, D.O. Shah, B.J. Palla, Electrochem. Solid-State Lett. 2 (3) (1999) 148-150.

[11] L. Zang, S. Raghavan, M. Weling, J. Vacuum Soc. Technol. B 17 (5) (1999) 2248-2255.

[12] E.A. Kneer, C. Raghunath, V. Mathew, S. Raghavan, J. Electrochem. Soc. 144 (9) (1997) 3041-3049.

[13] D.A. Jones, Principles and Prevention of Corrosion, second ed., Prentice Hall, Upper Saddle River, NJ, 1983.

[14] M. Pourbaix, Atlas of Electrochemical Equilibria in Aqueous Solutions, NACE, Houston, TX, 1975.

[15] H.E. Johnson, J. Leja, J. Electrochem. Soc. 112 (1965) 638.

[16] F.W. Preston, J. Soc. Glass Technol. 11 (1927) 214. 